\title{
PHILOSOPHICAL ANALYSIS OF THE PROBLEM OF INFORMATION PSYCHOLOGICAL SECURITY
}

\author{
J.K. Biyimbetov
}

\begin{abstract}
This article highlights the peculiarities of information psychological security. The concept of psychological protection in the narrow sense leads to a special change in the content of consciousness as a result of the action of a number of defense mechanisms: amplification, projection, identification, regression, isolation, rationalization, conversion and others. The action of these protective mechanisms does not increase the adequacy of human behavior and information-orienting barriers of his system of subject-human relations, and in some cases may reduce their adequacy. Such an interpretation, formed within the bounds of a psychoanalytic approach, focuses on the neutralization of internal factors, which are usually ambiguous, but are usually caused by external influences. In such cases, barriers to the direct limitation of external influences, such as psychological manipulations of information and communication interactions at the social, socio-group, interpersonal levels, are neglected. The place and role of information psychological security in the life of human society is analyzed philosophically.
\end{abstract}

Keywords: Information, Civilization, Threat, Security, Global, Projection, Identification, Regression, Isolation, Rationalization, Conversion, Protection, Mental Life, Method of Protection.
Karakalpak State University,

Nukus, Uzbekistan

Corresponding Author:

J. Biyimbetov,

jasik5705@gmail.com

Reference to this article:

Biyimbetov J.K. Philosophical Analysis of the Problem of Information Psychological Security // Adam alemi.

- 2021. - No. 2 (88). - P. 3-9.

\section{Ақпараттық психологиялық қауіпсіздік мәселесінің философиялық талдауы}

Аннотация. Мақалада ақпараттық психологиялық қауіпсіздік ерекшеліктері көрсетілген. Тар мағынадағы психологиялық қорғаныс ұғымы бірқатар қорғаныс механизмдерінің: күшейту, проекциялау, сәйкестендіру, регрессия, оқшаулану, рационализация, конверсия және басқаларының әрекеті нәтижесінде сана мазмұнының ерекше өзгеруіне әкеледі. Осы қорғаныс механизмдерінің әрекеті адамның мінез-құлқының адекваттылығы мен оның субъективті-адами қатынастар жүйесінің ақпараттық кедергілерін арттырмайды, ал кейбір жағдайларда олардың жеткіліктілігін төмендетуі мүмкін. Психоаналитикалық көзқарас шеңберінде қалыптасқан мұндай интерпретация әдетте екіұшты, бірақ көбінесе сыртқы әсерден болатын ішкі факторларды бейтараптандыруға бағытталған. Мұндай жағдайларда сыртқы әсерлерді тікелей шектейтін кедергілер, мысалы, әлеуметтік, әлеуметтік-топтық және тұлғааралық деңгейде психологиялық айла-шарғы жасау және коммуникативті өзара әрекеттесу ескерілмейді. Ақпараттық психологиялық қауіпсіздіктің адамзат қоғамы өміріндегі орны мен рөлі философиялық тұрғыдан талданған. Түйін сөздер: ақпарат, өркениет, қауіп, қауіпсіздік, ғаламдық, проекция, сәйкестендіру, регрессия, оқшаулану, рационализация, трансформация, қорғау, психикалық өмір, қорғау әдісі. 


\section{Философский анализ проблемы психологической безопасности информации}

Аннотация. В статье освещены особенности информационной психологической безопасности. Понятие психологической защиты в узком смысле приводит к особому изменению содержания сознания в результате действия ряда защитных механизмов: усиления, проекции, идентификации, регрессии, изоляции, рационализации, конверсии и других. Действие этих защитных механизмов не увеличивает адекватность поведения человека и информационные барьеры его системы субъектно-человеческих отношений, а в некоторых случаях может снизить их адекватность. Такая интерпретация, сформированная в рамках психоаналитического подхода, ориентирована на нейтрализацию внутренних факторов, которые обычно неоднозначны, но обычно вызваны внешними воздействиями. В таких случаях игнорируются препятствия для прямого ограничения внешних воздействий, такие как психологические манипуляции с информацией и коммуникативные взаимодействия на социальном, социально-групповом и межличностном уровнях. Философски проанализированы место и роль информационной психологической безопасности в жизни человеческого общества.

Ключевые слова: информация, цивилизация, угроза, безопасность, глобальное, проекция, идентификация, регресс, изоляция, рационализация, преобразование, защита, психическая жизнь, метод защиты.

\section{Introduction}

In the process of transition to a new civilization, humanity is analyzing the peculiarities of the new civilization. On the one hand, it provides a number of opportunities for human life, and on the other hand, it raises pressing issues that need to be addressed. One of them is the problem of information psychological security.

The concept of psychological protection in the narrow sense leads to a special change in the content of consciousness as a result of the action of a number of defense mechanisms: amplification, projection, identification, regression, isolation, rationalization, conversion and others. The action of these protective mechanisms does not increase the adequacy of human behavior and information-orienting barriers of its system of subject-human relations, and in some cases may reduce their adequacy. Such an interpretation, formed within the bounds of a psychoanalytic approach, focuses on the neutralization of internal factors, which are usually ambiguous, but are usually caused by external influences. In such cases, barriers to the direct limitation of external influences, such as psychological manipulations of information and communication interactions at the social, socio-group, interpersonal levels, are neglected. Therefore, let's pay close attention to the study of the "interpersonal" approach to the study of psychological protection from the manipulative influence, developed by $\mathrm{E}$. Dotsenko. From this point of view, psychological protection is considered as a special phenomenon of intersubjective interaction [1]. The main function of psychological protection is to prevent the internal stability of the individual and society, the normal flow of mental life and behavior under the influence of socially harmful influences.

\section{Methods}

Within the framework of this method, psychological protection should be considered as a function of the individual, which defines the combined structuralfunctional system. In this system, the interconnected components - the worldview, which includes a person's views, beliefs, worldview, suspicion, disbelief, and other activities, including consciousness, antipathy, fear, etc. can be specified. Thus, all the methods used to study the psychological protection of a person indicate that a person has two independent and sufficiently autonomous special regulatory systems of psychological protection that protect him 
from internal psychological discomfort and external psychological influences. These systems have a complex structure and are implemented through various psychological mechanisms.

Psychological protection from external influences is carried out through the following types of barriers:

First, pre-established and undefined psychological protections. The first is done in accordance with the intentions of the people affected. The second is activated under the influence of external influences.

Second, individual and group psychological protections. The individual is considered as the representative of the former, and the social group is considered as the representative of the latter.

Third, sonic and special psychological protections. In the first, the toxicity of a person in relation to external influences is realized. It is wide and covers most of the external influences, but in spite of this it gives a weak resistance to external influences. Special psychological protection has a narrow scope of action, which may be manifested in a specific subject or in a certain content of the impact, but has a great power.

\section{Philosophical Analysis of Information Security}

Psychological protection from external influences is characterized by selectivity and dynamism. Selectivity is the effect of an object itself in the formation of different degrees of resistance to different subjects, to different content emanating from one subject. The dynamism of psychological protection is reflected in the oscillations of its real action.

There are two types of psychological protection:

The first is that psychological protection is considered in the traditional psychoanalytic orientation as internal psychological protection.

The second is the protection from external influences and its specific forms of expression - interpersonal, individual, group or collective psychological protection. We can combine them with the concept of "social and psychological" protection.

Protection is considered as a negative concept of information psychological protection. To reveal the content of the concept of "protection" we use a diagram that includes four elements: 1) the subject of protection; 2) danger; 3) damage; 4) method of protection.

Given the social context and interpersonal relationships, it is necessary to change the scheme to explain the concept of protection as a negative concept, and to expand another element the introduction of the subject of protection. When modified and expanded, it has the following content.

First, we need to determine whether something is protected or whether it is the object or subject of protection.

Second, we need to determine what we are defending. What is the danger we need to know what is the threat of the external factor that affects the given Putin.

Third, what we should avoid, what we should avoid, what specific harm should be avoided - destruction, destruction, separation or isolation, subjugation, etc.

Fourth, how can we avoid possible harm and how can we protect ourselves? That is, we must determine the methods and means of protection from the specifics and capabilities of the subject of protection, the characteristics of the threat (threat factors).

Fifth, Kim defends. That is, we must determine who will be the subject of human protection (individual, person, group, social group, society, state) [2].

In addition, the term "protection" is used in two senses. First, protection means what we protect, that is, a certain systemicstructural structure, and secondly, protection is considered as an action, that is, it gives the process of survival of a given system [3].

According to this diagram, the system of psychological protection is interpreted as a different concept in relation to the concept of protective genealogy, with the help of its given points separately or in connection with each other.

Let's stop at the above points. 
1) Object and subject of psychological protection. The object is considered to be some kind of Putin, which is separated from the object. As a subject of psychological protection, the social subject or other subjects influencing the psychological correction are considered as objects of psychological protection - for example, if we consider the object of psychological protection as an object of psychological protection, its psyche, certain psyche, human structures provide protection).

Thus, the object of psychological protection is considered as a social subject of any degree of system-structural and functional structure, of various degrees of composition, and its subject as a whole mental structures and processes as elements of its structure. Objects are the state, society, various social groups, groups and associations of people, individuals.

In the literature on psychology, the subject of protection is usually considered to be the human psyche or some mental structure, a whole inner human structure. The subjects of protection are, first of all, self-esteem, self-confidence, self-concept, self-image, individuality. In addition, the subjects of protection are considered in the motivational structures (desires, wishes, tastes), cognitive structures (worldview, opinion, knowledge), behavioral manifestations (habits, abilities, attitudes, behaviors, business style). But behind all these appearances, there is a whole human being who protects himself, his integrity, his personal appearance and his qualities.

2) Risk factors. In the context of psychological protection, we can mention the following: firstly, the external threats that explain the actions of individuals, groups, associations of people, social institutions, society and the state, which pose a threat to the human being in the first place, and secondly, in all its forms and manifestations.

3) The nature of the damage. The specific damage is biased from the object of protection itself. For a person, it is a violation of self-esteem or not, a disorientation in the environment, a violation of the adequacy of one's views on the world around him and his place in it, a decrease in self-esteem or faith, a lack of morality, in the choice of methods and goals, in the psychological bias of the affected subjects, in the mental degradation, in the deterioration of mental health.

Thus, in any case, the damage means various degrees of damage to the mental structures and structures of the individual, leading to the complete destruction of subjectivity and personality. The following types of possible damage to social entities of different levels of composition, systemicstructural and functional structure can be distinguished: Complete disintegration, oppression or subordination, separation or isolation, qualitative change.

4) Means of psychological protection. In our opinion, a tool is a method, a way, an image of actions that are aimed at achieving or implementing something. In addition, we use tools to identify things that are needed for a specific purpose. For example, psychological protection in a person includes a system of clear structures, in particular, the use of knowledge, diaries, skills to implement certain forms of selfprotective behavior.

Means of psychological protection of the individual, for example, include mechanisms of internal protection of the person and the basic principles of protection described above. Thus, when looking at methods of psychological protection, we need to pay attention to the identification and training of risk factors (the formation of specific structures necessary for the implementation of protective behaviors).

Methods of psychological protection of a person are associated with changes in the processes of communication and psychological interaction with various social actors and the information center in order to eliminate or neutralize the risk factors that can harm a person.

5) Subjects of protection. The group is considered as a subject of psychological protection of a specific person.

As subjects of psychological protection of the person:

Firstly, the individual and the whole psychological structures of the inner 
personality (for example, I), secondly, other people who help and support by psychological means, various groups and social units, and thirdly, the society and the state (influencer).

The concept of psychological protection of the individual can be defined by limiting and narrowing the meaning of "protection", which is a single concept, and using the above five parameters. As a special feature of the concept of "psychological protection" is considered the use of methods associated with the regulation and modification of the processes of information and psychological interaction with various social entities and the information center. The processes of information and psychological interaction of a person can be changed both by him and by other people and social entities of different levels, if they arise from his desires.

\section{Results}

The study of explanatory dictionaries showed that when defining the concept of "safety", the emphasis is on the state and experiences of a person associated with his position in the present, prospects for the future and a sense of security from various kinds of dangers. For example, in the «Big Explanatory Dictionary of the Russian Language» security is defined as the absence of danger, threat, harmlessness [8, p. 67], and the danger is the threat of disaster, misfortune, catastrophe $[8, p$. 715]. In the international documents of the IAEA it is noted that safety is the state of protection of a person, society and the environment from excessive danger. In this case, the concept of "excessive danger" is disclosed in the following context: security is a property of real processes and systems containing sources of threats and their possible victims, to maintain a state with an acceptable possibility of damage caused by incidents [9].

G. Allport is considered to be one of the founders of the definition of personality [10]. Having proposed about 50 definitions, in 1937 he dwelt on the fact that personality is a dynamic organization in a person of those mental and physiological systems that determine his thinking and behavior. In our opinion, the variety of definitions of the concept of "personality" is due to the multitude of structure-forming components of the personality and the complexity of establishing connections between them. Obviously, all the diversity of points of view on the theory of personality can be reduced to the following three, which represent different options for the relationship of biopsychosocial in the structure of personality. The first point of view includes the positions of those researchers who consider the concepts of "human essence" and "personality" to be identical (A.G. Myslivchenko, P.E. Kryazhev). The second point of view is that personality is the integration of the biological and the social (KK Platonov, BD Parygin). The third point of view unites the opinions of those authors who consider the essence of a person as a social and natural factor in his development, and the personality as a system of his stable qualities, properties realized in social relations, social institutions, culture, and more broadly in social life (B. G. Ananiev, E. Anufriev, L.P.Bueva, I.S.Kon, Yu.V. Sychev, V.F.Serzhantov, A.G. Spirkin, A.G. Efendiev, V.A.Petrovsky) ...We will rely on the position of A.V. Petrovsky that a person is a person as a social individual, a subject of cognition and objective transformation of the world, a rational being with speech and capable of labor activity [6]. Personality is a product of human existence; the carrier of a set of socially significant traits and mental properties that have developed in the process of ontogenesis and determine the behavior of an individual as a conscious subject of activity and social relations.

Information exists in countless descriptions of specific material and non-material forms, objects, processes. Experts classify information on different grounds: form (discrete or continuous); areas of origin (elementary (mechanical), biological, social), method of transmission and perception (visual, auditory, tactile, organoleptic, machine), public purpose 
(personal, mass, special), coding methods (symbolic, textual, graphic). We propose to consider information as a semantic, meaningful aspect of signals registered and transformed by the subject into known concepts.

Summarizing the above, we note that the philosophical aspect of the information and psychological security of the individual consists in the worldview awareness of the personality of the state of protection of vital interests from external and internal dangers and threats, as well as social practices of safe behavior [11].

The formation of information and psychological security of a person can be based on the following principles:

1) centralization, which stipulates the creation of a complex of legal and moral norms, public institutions and organizations that ensure the state of protection of the individual from various information influences, as well as an adequate system of his relations to the world around his and hisself;

2) legitimization, providing the process of formation of information and psychological security of the individual public recognition and presupposing the creation of psychological mechanisms of (self) regulation;

3) implicitness, providing for the development of mechanisms of psychological protection, ensuring the protection of consciousness from negative information influences;

4) amplification, which causes an increase in the awareness of the individual about information-psychological dangers and threats, as well as the formation and maintenance of a stable focus on the development of mechanisms of information-psychological self-defense.

\section{Conclusion}

Psychological protection of the associated person means the identification or neutralization of risk factors that can harm a person through the use of various tools and methods of changing the processes of communication and psychological interaction with various social actors and information centers. In other words, the psychological protection of the individual means the use of tools and methods that change the processes of communication and psychological interaction with various social actors and the message center in order to eliminate or neutralize the risk factors that can harm a person. In summary, information psychological security is one of the problems to be addressed in the development of the state. Therefore, the study of the specific aspects of information psychological security is necessary for science.

\section{References}

1. Чернов А.А. Становление глобального информационного общества: проблемы и перспективы - Монография//М., 2003, «Дашков и К ${ }^{\circ}$. - 251 с.

2. Романова Е., Гребенников Л. Механизмы психологической защиты. Генезис. Функционирование. Диагностика. 1996. - C. $42-57$.

3. Берн Э. Игры, в которые играют люди. Психологиячеловеческихвзаимоотношений; Люди, которые играют в игры. Психология человеческой судьбы. - СПб.: Лениздат, 1992. - 400 с.; Психологические операции и противодействие им. - М., 1993. - 251 с.

4. Berdimuratova A. K., Mukhammadiyarova A. J. Philosophical and methodological aspects of the interaction of natural environment and man // International Journal of Pharmaceutical Research. 2020, 12(3). - P. 235-245.

5. Pirnazarov N. Philosophical analysis of the issue of spirituality // International Journal of Advanced Science and Technology. 2020, 29(5). - P. 1630 - 1632.

6. Pirnazarov N. Influence of Virtual Reality on the Spirituality of Information Society. // Евразийский Союз Ученых. Философские науки. 2020, 71(2). - С. 41-45.

7. Pirnazarov N., Eshniyazov R., Bezzubko B., Alimov A., Arziev A., Turdibaev A. Bachelor Degree Programs in Building Materials Technology // European Journal of Molecular \& Clinical Medicine. 2021, 7 (10). - P. 1780-1789.

8. The Big Explanatory Dictionary of the Russian Language / comp. and ch. editor S.A. Kuznetsov. - SPb.: Norint, 2000. 
9. Efimova N. Fundamentals of psychological safety: textbook. allowance. - M.: Publishing House "FORUM": INFRA, 2010.

10. Allport G. Formation of personality: Selected works / [per. from English L.V. Trubitsyna and D. A. Leontyev]; under total. ed. YES. Leontyev. - M.: Smysl, 2002.

11. Lunev A.N., Pugacheva N.B. Social practice as a philosophical basis for pedagogical strategizing in a technical university // Society: philosophy, history, culture. - 2013. - No. 4. - P. 22.

\section{Transliteration}

1. Chernov A.A. Stanovlenie global'nogo informacionnogo obshhestva: problemy i perspektivy [Formation of the global information society: problems and prospects]. - Monografija//M., 2003, «Dashkov i K». - 251 s. (in Russ)

2. Romanova E., Grebennikov L. Mehanizmy psihologicheskoj zashhity. Genezis. Funkcionirovanie. Diagnostika [Psychological defense mechanisms. Genesis. Functioning. Diagnostics]. 1996. - S. 42-57. (in Russ)

3. Bern Je. Igry, v kotorye igrajut ljud [Games People Play]. Psihologija chelovecheskih vzaimootnoshenij; Ljudi, kotorye igrajut v igry. Psihologija chelovecheskoj sud'by. - SPb.: Lenizdat, 1992. - 400 s.; Psihologicheskie operacii i protivodejstvie im. - M., 1993. - 251 s. (in Russ)

4. Berdimuratova A. K., Mukhammadiyarova
A. J. Philosophical and methodological aspects of the interaction of natural environment and man // International Journal of Pharmaceutical Research. 2020, 12(3). - P. 235-245. (in Eng)

5. Pirnazarov N. Philosophical analysis of the issue of spirituality // International Journal of Advanced Science and Technology. 2020, 29(5). - P. 1630-1632. (in Eng)

6. Pirnazarov N. Influence of Virtual Reality on the Spirituality of Information Society. // Evrazijskij Sojuz Uchenyh. Filosofskie nauki. 2020, 71(2). - S. 41-45. (in Eng)

7. Pirnazarov N., Eshniyazov R., Bezzubko B., Alimov A., Arziev A., Turdibaev A. Bachelor Degree Programs in Building Materials Technology // European Journal of Molecular \& Clinical Medicine. 2021, 7 (10). - P. 1780-1789. (in Eng)

8. The Big Explanatory Dictionary of the Russian Language / comp. and ch. editor S.A. Kuznetsov. - SPb.: Norint, 2000. (in Eng)

9. Efimova N. Fundamentals of psychological safety: textbook. allowance. - M.: Publishing House "FORUM": INFRA, 2010. (in Eng)

10. Allport G. Formation of personality: Selected works / [per. from English L.V. Trubitsyna and D. A. Leontyev]; under total. ed. YES. Leontyev. - M.: Smysl, 2002. (in Eng)

11. Lunev A.N., Pugacheva N.B. Social practice as a philosophical basis for pedagogical strategizing in a technical university // Society: philosophy, history, culture. - 2013. - No. 4. - P. 22. (in Eng).

\section{INFORMATION ABOUT AUTHORS}

Jaksilik Biyimbetov

Жақсылық Қилышбайұлы Биімбетов

Жаксилик Килишбаевич Бийимбетов
Assistant professor, Karakalpak State University, Nukus, Uzbekistan

Ассистент оқытушы, Қарақалпақ мемлекеттік университеті, Нөкіс, Өзбекстан

Ассистент преподаватель, Каракалпакский государственный университет, Нукус, Узбекистан 